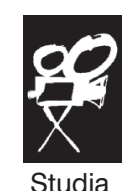

Filmoznawcze

37

Wrocław 2016

\title{
Sławomir Bobowski
}

Uniwersytet Wrocławski

\section{TEMATYKA UKRAIŃSKA W POWOJENNYM POLSKIM FILMIE FABULARNYM DO 1989 ROKU}

DOI: 10.19195/0860-116X.37.7

W Polsce powojennej powstały w latach 60. trzy filmy nawiązujące do walk Ludowego Wojska Polskiego z oddziałami Ukraińskiej Powstańczej Armii (UPA) w Bieszczadach pod koniec wojny i w podczas kilku powojennych miesięcy. Wszystkie trzy realizowane były z myślą o stworzeniu mitu bieszczadzkiego o oddziaływaniu propagandowym. Wszystkie też mają formę nieco zbliżoną do westernu, gatunku niezwykle popularnego w okresie ich powstawania, formę, która miała realizację obu tych zadań — mitotwórczego i propagandowego — ułatwić.

\section{TRYPTYK O WALKACH Z UPA}

\section{OGNIOMISTRZ KALEŃ (1961)}

Film Ewy i Czesława Petelskich stanowi część fenomenu Polskiej Szkoły Filmowej, a konkretnie jej nurtu plebejskiego, czyli grupy filmów (jak np. Krzyż walecznych Kutza (1958), Rok pierwszy (1960) czy Kwiecień (1961) Witolda Lesiewicza albo Wolne miasto (1958) Stanisława Różewicza) eksponujących i nobilitujących bohatera ludowego. Podstawę scenariusza stanowiła powieść Jana Gerharda Łuny w Bieszczadach (I wyd., 1959), bardzo popularna w PRL-u, wielokrotnie wznawiana, a ze względu na „walory” ideologiczno-propagandowe zalecana przez władze państwowe do wykorzystywania w edukacji szkolnej jako lektura obowiązkowa. 
Pisarz, odwołując się głównie do przeżyć z własnej biografii ${ }^{1}$, ukazał w powieści walki wojska Polski Ludowej z oddziałami Ukraińskiej Powstańczej Armii (UPA) i współdziałającymi czasem z nią oddziałami Armii Krajowej. Powieść jest próbą oddania skomplikowanej sytuacji polityczno-społecznej okresu tuż po wojnie na południowo-wschodniej ścianie Polski — w Bieszczadach. Próbą jednakże mocno zideologizowaną i nierzetelną pod kątem relacji wobec prawdy historycznej i politycznej.

Spośród licznych wątków powieści autorzy filmu wybrali niepierwszoplanową postać ogniomistrza Kalenia, ale wzbogacili ją o cechy i motywy biograficzne kilku innych postaci Gerhardowskiej fabuły, przez co stworzyli ,postać barwną, mającą w swym rodowodzie zarówno pewne cechy Costerowskiego Dyla Sowizdrzała, Sienkiewiczowskiego Kmicica, jak i współczesnego żołnierskiego wygi, który lubi wypić, ma powodzenie u kobiet, czasem chętnie powojuje, a przecież liczy dni, kiedy wróci do cywila"2. W istocie postać tytułowa, w ogromnym stopniu dzięki wspaniałemu aktorstwu Wiesława Gołasa, jest bardzo jasnym punktem filmu. Kaleń to typ realistyczny i jednocześnie silnie zindywidualizowany, czego skutkiem jest m.in. jego piękny heroizm i tragizm, kiedy w finale filmu ginie od kuli swoich, osłaniając swym ciałem dziecko ukraińskie.

Film posiada także inne atuty warsztatowe przybliżające go do pięknej wartości estetycznej, jaką jest realizm. Zrealizowano go prawie wyłącznie w Bieszczadach. Akcja wielu fragmentów ulokowana została w autentycznych miejscach zmagań wojennych sprzed kilkunastu lat. W kadrach widać jeszcze pozostałości autentyczne walk, takie jak opustoszałe obszary ziemi, spalone wioski, zniszczone mosty. „Nie trzeba było - czytamy w opracowaniu Stanisława Ozimka — dla potrzeb filmu zmieniać scenerii Baligrodu, miasteczka ukazanego w pierwszej partii filmu; było ono rzeczywiście opustoszałe, na wpół zrujnowane, z zaledwie kilkoma zamieszkałymi domostwami"3. Zdjęcia Mieczysława Jahody eksponują posępność i surowość bieszczadzkiego, bezludnego pejzażu. Kadry i sceny przybliżają specyficzne, charakterystyczne typy południowo-wschodnie, jak np. ziemianin Dwernicki, który przechowuje starą, XVII-wieczną hakownicę, wykorzystaną zresztą w walce oddziału milicji z żołnierzami NSZ. Bardzo ciekawe jest to, iż w realizacji scen zbiorowych statystowali m.in. statyści ukraińskiego pochodzenia, którzy też nierzadko stanowili źródło informacji na temat tego, ,jak to było" w czasie owych walk z oddziałami UPA. Przynosili również na plan filmowy uzbrojenie z tamtych czasów:

Gdy trzeba było uruchomić niemiecki karabin maszynowy — wspominają Petelscy — a nie mieliśmy amunicji, statyści przynieśli skrzynkę naboi na plan. Oczywiście upewnili się najpierw:

${ }^{1}$ Gerhard w latach 1945-1952 był żołnierzem Wojska Polskiego, m.in. dowódcą 34. Pułku Piechoty. W tej funkcji uczestniczył w walkach z UPA w Bieszczadach.

2 S. Ozimek, Film fabularny, [w:] Historia filmu polskiego, red. J. Toeplitz, Warszawa 1980, s. 119.

3 Ibidem.

Studia Filmoznawcze 37, 2016

(C) for this edition by CNS 
„A ne skażete...”. Po odebraniu broni od statystów okazało się, że zamiast naszego pistoletu z przewierconą lufą, do rekwizytorni wrócił autentyczny, sprawny, niemiecki ${ }^{4}$.

Walczą w filmie polskie oddziały wojska ludowego z grupami UPA, których wspomagają, ze względów taktycznych, żołnierze WiN-owskiego i NSZ-owskiego podziemia 5 . Walki są gwałtowne i krwawe. Atakują głównie banderowcy, których jest więcej od Polaków, znają świetnie teren i mogą liczyć na wsparcie miejscowej ludności. Są okrutni i bezwzględni. Kadry eksponują wisielców kołyszących się na stokach Halicza, a polscy żołnierze wzięci do niewoli są traktowani potwornie barbarzyńsko torturowani i ścinani toporem w makabrycznym obrzędzie nacjonalistycznym: znęcaniu się na żołnierzach towarzyszy dzikie skandowanie oprawców: „Bandera! Bandera!” W innej scenie nacjonaliści ukraińscy zabawiają się urządzeniem polskim kilku żołnierzom swoistego danse macabre. Nie wystarczy im, że biedni polscy wojacy stoją na polu minowym, dla większej uciechy strzelają im pod nogi, aby chłopcy tańczyli.

Część krytyków, o czym już wspominałem, analizowała i interpretowała Kalenia jako polski western, ale przecież ten całkiem niezły obraz wojenny tylko powierzchniowo przypomina formułę amerykańskiego kina. Głównym elementem różniącym obraz Petelskich od tejże formuły jest właśnie koncepcja protagonisty. Zwłaszcza jego śmierci, która w przeciwieństwie do westernu, gdzie jest na niby, została ukazana bez upiększeń, bez optymistycznych zmiękczeń. Kiedy w znakomitym westernie Martina Ritta pt. Hombre (1968) John Russell, „biały Indianin” (porwany w dzieciństwie przez Apaczów i wychowany wśród nich), grany przez Paula Newmana, ginie w finale za grupę tchórzliwych białych, to jeden $\mathrm{z}$ umierających od kuli Russella bandziorów pyta na sekundę przed zgonem: „Jak on miał do cholery na imię?!" W westernie bohater wygrywa, a jeśli nawet przegrywa, to z fasonem i optymistycznym akcentem. Tymczasem Kaleń, ranny i półprzytomny budzi się wśród wrogów w chacie z ukrywającymi się ukraińskimi kobietami i dziećmi, właśnie atakowanej przez polskich żołnierzy i ginie od ich kul, zasłaniając dziecko ukraińskie. Nie ma w tej ponurej scenie niczego atrakcyjnego. Jej jedyne piękno w postaci heroizmu prostego żołnierza przez nikogo nie zostanie zauważone. I o to chyba najbardziej chodziło Petelskim, o złożenie hołdu prostym, zwykłym, niezna-

4 Ibidem; Mówią Ewa i Czesław Petelscy, notował Czesław Dondziłło, „Film” 1974, nr 18.

5 WiN to skrót nazwy zrzeszenia Wolność i Niezawisłość, polskiej cywilno-wojskowej organizacji antykomunistycznej założonej 2 września 1945 w Warszawie. Jej trzon stanowiły pozostałości rozwiązanej w 1945 Delegatury Sił Zbrojnych na Kraj. NSZ — skrót nazwy Narodowe Siły Zbrojne, oznaczającej polską konspiracyjną organizację wojskową obozu narodowego, działającą podczas II wojny światowej i w okresie powojennym. Narodowe Siły Zbrojne w czasie okupacji liczyły według różnych danych od 80 tys. (w październiku 1943 72,5 tys.) do 100 tys. ludzi. Organizacja walczyła z Niemcami i zwalczała partyzantkę komunistyczną (Gwardię Ludową/Armię Ludową i partyzantkę radziecką) oraz bandy rabunkowe. 
nym żołnierzom zaświadczającym nie raz na wojnie, że istnieją wartości ponadnarodowe, ponadpolityczne.

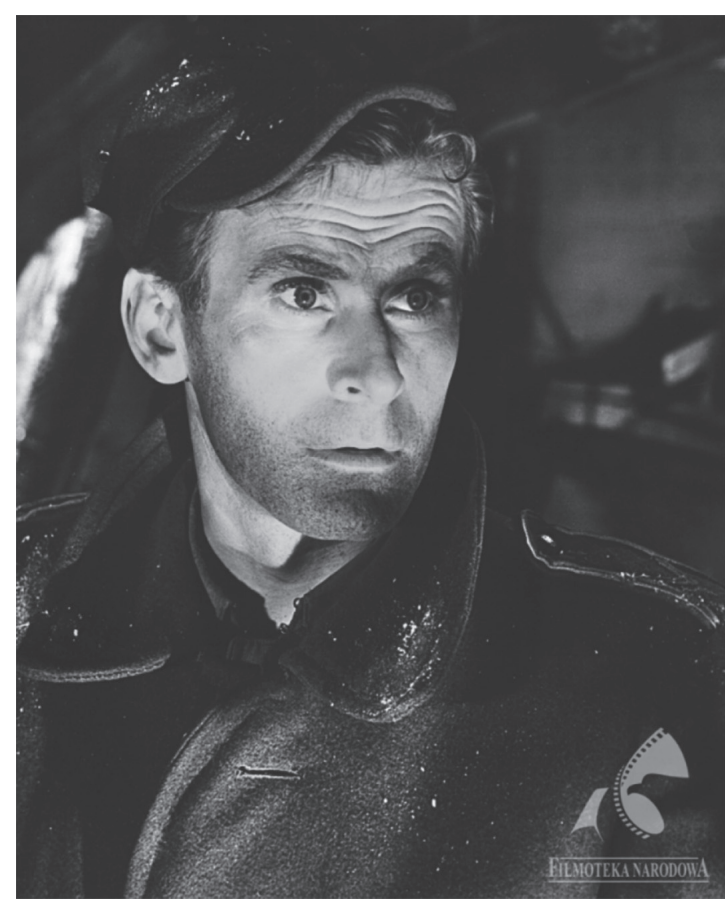

1. Wiesław Gołas jako Kaleń. Ogniomistrz Kaleń, reż. Ewa i Czesław Petelscy, 1961. Fot. Erol Feridun, (CSF KADR, SF TOR, SF ZEBRA. Filmoteka Narodowa. Licencja: SF KADR

Konwencja westernu nie zakorzeniła się w polskiej tradycji filmu wojennego. Stanisław Ozimek tłumaczy, dlaczego tak się stało ${ }^{6} \mathrm{w}$ tematyce wojennej:

Jedną z przyczyn niepowodzeń można upatrywać w tym, że gatunek ten nie ma tradycji w polskiej kinematografii, ale przede wszystkim — w braku historycznego dystansu do ukazywanych wydarzeń $\mathrm{i}$ ich protagonistów. Wielki exodus na Ziemie Odzyskane czy krwawe wydarzenia w Bieszczadach nie obrosły jeszcze legendą, nie poddane były ani mitologizacji, ani tym bardziej — w konsekwencji ,uszlachetnienia” gatunku westernu — demitologizacji ${ }^{7}$.

${ }^{6}$ Autor wymienia inne filmy kojarzące się z westernami: Prawo i pięść (1964) Edwarda Skórzewskiego i Jerzego Hoffmana, Pigułki dla Aurelii (1958) Stanisława Lenartowicza oraz Droga na zachód (1960) Bohdana Poręby. Ja dodałbym Zerwany most i Wilcze echa, o których będzie mowa w niniejszym artykule.

7 S. Ozimek, op. cit., s. 121. 
Ozimek nie zadaje pytania, dlaczego ta mitologizacja nie dokonała się. Wydaje mi się, że nie mogła się dokonać, skoro temat walk z oddziałami UPA był ściśle pilnowany przez władze państwowe. Wielu widzów polskich nie orientowało się w tym, co naprawdę działo się na przełomie końca wojny i początku czasu pokoju na terenach bieszczadzkich. Tym bardziej nie wiedziało o zakorzenieniu tych wydarzeń w przeszłości, m.in. w działalności nacjonalistów ukraińskich podczas wojny, czego częścią były bestialstwa dokonywane przez nich na Polakach na Wołyniu, Podolu czy Pokuciu w roku 1943. Podobnie było z całą wojną w kinie i literaturze PRL-u — nic nie mogło się na dobrą sprawę mitologizować, ponieważ wszystko było pilnowane, reglamentowane, obwąchiwane. A tworzenie legendy wymaga swobody, jest żywiołowe, niekontrolowane. Musi być procesem szczerym, autentycznym. Ozimek widzi raczej powiązania Kalenia z „okrutną balladą”, trochę analogiczne w duchu do Bazy ludzi umartych (również w reżyserii E. i Cz. Petelskich, 1958) dzieło „wyobcowane z nurtu «szkoły polskiej»”. Według Ozimka problem odwagi i bohaterstwa został potraktowany „niekonwencjonalnie”. Chociaż „samotnicza ofiara życia Kalenia, który powiększył jednocześnie galerię postaci o ludowym, plebejskim rodowodzie — nie przekreśla jednak związków dzieła Petelskich z wchodzącą już w swój schyłkowy okres «szkołą polską»" tach w wywiadzie dla „Filmu” zaprzeczyli, że chcieli nakręcić film polemiczny do „szkoły polskiej”, że raczej szukali „polskiego nurtu romantyki rewolucyjnej” i że blisko im było do Czapajewa9 ${ }^{9}$.

Zostawmy Kalenia, w istocie ciekawą postać, bohatera wykraczającego poza jakiekolwiek spory ideologiczne, zdroworozsądkowego zucha obdarzonego instynktem etycznym, a przy tym niebanalnym poczuciem humoru, jednego z najciekawszych protagonistów polskiego kina. Zwróćmy uwagę na portret czasów walk w Bieszczadach o ich polskość, na stosunek filmu do skomplikowanej materii historyczno-politycznej, której dotyka. Można odnieść wrażenie, że owe czasy są ukazane w obrazie Petelskich jakby bez komunistycznego nachylenia ideologicznego, a jeśli je jednak odkrywamy, to stwierdzamy, iż jest nienadmiernie widoczne, nienachalne. Wojna światowa jest skończona, działania zarówno oddziałów polskich niedobitków Armii Krajowej, jak i partyzantów UPA nie mają sensu; walczą jednak oddziały polskie WiN-u i NSZ-u, które z przyczyn wojskowo-strategicznych współpracują z oddziałami UPA; te ostatnie są najaktywniejsze, wrogie Polsce i komunistom; choć udaje im się mieć niejaką przewagę nad polskimi żołnierzami ludowymi, skazani są już na klęskę, co uwydatnia postawa kochanki przywódcy (prowidnyka) „Bira” (granego przekonująco przez Leona Niemczyka), kobiety niewierzącej w jakikolwiek sens ukrywania się i wojowania; upowcy są bezwzględni i okrutni, scena z obcinaniem głów polskim jeńcom jest przejmująca. Nachylenie komunistyczne
8 Ibidem.
9 Ibidem. 
widać w ukazaniu polskich żołnierzy wyklętych, oddziału WiN majora Żubryda (Edward Kłosiński) — nie tylko w ich wrogości wobec żołnierzy Polski Ludowej, w bezwzględności wobec nich jako wrogów (złapany Kaleń jest męczony przez rodaków, a inny młody żołnierz zostaje bezceremonialnie zastrzelony przez Żubryda). Reżyserzy nie odmówili sobie socjalistycznej, nikczemnej w swej istocie, pogardliwej aluzji do „pańskich” korzeni oddziałów polskiego wojska wywodzących się z Armii Krajowej, kiedy w scenie zatrzymania przez oddział Żubryda żołnierzy Armii Ludowej kamera z lubością uwydatnia czyste jak tafla wody oficerki jednego z żołnierzy WiN-u, właśnie w tym kontekście — symbolu przedwojennej Polski „pańskiej”, szlacheckiej. Żeby owa dyskredytacja polskich żołnierzy wyklętych była jeszcze pikantniejsza, Dwernicki, rasowy w postawie i zachowaniu polski ziemianin/arystokrata, godzący się z rozsądku na nowy porządek, znakomicie reprezentuje polską szlachtę, jej dumę i nieugiętość, kiedy ma być stracony przez Żubryda; nawet w obliczu śmierci upokarza tego ostatniego, drwiąc z jego głupoty i tępoty przejawiającej się w nieprzyjmowaniu faktów do wiadomości (tu: końca wojny i bezsensowności zbrojnego oporu).

Film Petelskich, choć - jak wykazałem — nie jest pozbawiony tendencyjności, jawi się wobec źródła literackiego, powieści Gerharda, jako znacznie bardziej uczciwy historyczno-politycznie. Zarówno w ukazaniu zmagań LWP z UPA, jak i w portrecie polskich żołnierzy wyklętych.

\section{JAK BYŁO W BIESZCZADACH W LATACH 1945-1947}

Polska w wyniku ustaleń aliantów ze Stalinem utraciła Kresy Wschodnie. Żeby nową granicę polsko-sowiecką zabezpieczyć, Stalin powziął decyzję o wymianie ludności.

Odpowiednią umowę Polski Komitet Wyzwolenia Narodowego i rząd Ukraińskiej Socjalistycznej Republiki Radzieckiej podpisały 9 września 1944 r. Na jej podstawie Ukraińcy mieli opuścić Polskę, a Polacy USRR. Według oficjalnych danych w trakcie prowadzonych w latach 1944-1946 wysiedleń wyjechało z Polski ok. 488 tysięcy, zaś z Ukrainy 789 tysięcy osób ${ }^{10}$.

Ze strony ukraińskiej, tej niepogodzonej z porządkiem komunistycznym, przeciwstawiały się temu nowemu porządkowi OUN (Organizacja Ukraińskich Nacjonalistów) i jej zbrojne ramię — UPA. W kontekście walk o Bieszczady obie organizacje były przez lata, a i są niejednokrotnie nadal, mitologizowane. Po stronie ukraińskiej wielu widziało w nich jedynie szlachetne organy broniące Ukraińców przed przymusowymi wysiedleniami. $Z$ kolei po stronie polskiej istnieje tendencja do ujmowania działań obu organizacji jako bandyckich, skoncentrowanych na idei mordowania Polaków, będącej w Bieszczadach prostą kontynuacją rzezi na Woły-

10 G. Motyka, W kręgu Łun w Bieszczadach, Warszawa 2009, s. 12. 
niu roku $1943^{11}$. Konflikt między Polakami a ukraińskimi Bojkami czy Łemkami istniał w Bieszczadach już w II Rzeczypospolitej, ale był on bardziej widoczny na poziomie oficjalnych działań politycznych, a znacznie mniej w codziennym życiu mieszkańców Bieszczadów, gdzie mieszanych, polsko-ukraińskich rodzin było wiele $^{12}$. W czasie okupacji sowieckiej i hitlerowskiej nie było między Polakami a Bojkami czy Łemkami jakichś szczególnie dramatycznych kolizji. Działały jednak struktury OUN i UPA, których dążenia do depolonizacji (i również desowietyzacji) terenów Bieszczadów bardzo nasiliły się w lecie roku 1944. W tym czasie upowcy rozrzucali ulotki żądające opuszczenia przez Polaków Bieszczadów, grożąc im śmiercią w razie nieposłuszeństwa. „Jednocześnie przystąpiono do krwawych antypolskich akcji" "13. Największe masakry miały miejsce 6 sierpnia w Baligrodzie (42 osoby) i Mucznem (74 osoby). Ukraińcom przeciwstawiali się żołnierze z konspiracji AK, a także oddziały samoobrony. Niektóre z tych ostatnich współdziałały $\mathrm{W}$ walce $\mathrm{z}$ upowcami i hitlerowcami z partyzantami sowieckimi ${ }^{14}$. Po zakończeniu działań wojennych $\mathrm{z}$ hitlerowcami na terenach Bieszczadów, stanowiących część województwa rzeszowskiego, zaczęła tworzyć się administracja podległa PKWN (pierwszemu komunistycznemu rządowi polskiemu, powstałemu w Lublinie 1944). Oddziały UPA nie rezygnowały z walki — zarówno z Polakami, jak i sowietami - licząc na trzecią wojnę światową i utworzenie niezawisłej Ukrainy w granicach wymarzonych przez nacjonalistycznych ideologów OUN. W połowie roku 1945 nie było zbyt wielu potyczek między oddziałami UPA i polskiej milicji czy wojska ludowego. Było nawet tak, iż powstała dwuwładza. Sytuacja zaogniła się, gdy władze polskie, widząc żywą niechęć Ukraińców do idei przesiedlenia na wschód, zaangażowały do realizacji akcji wysiedleńczej Wojsko Polskie. Działania przesiedleńcze rozpoczęły się we wrześniu 1945 roku. „Towarzyszyły im liczne wypadki maruderstw, kradzieży i gwałtów popełnianych przez żołnierzy, a nierzadko też dowódców"15. Dowództwo OUN i UPA od razu przystąpiło do działań obronnych, nakazując jednak, aby ich partyzanci nadawali akcjom charakter antykomunistyczny, a nie antypolski: „Dlatego zakazywano palenia polskich wsi i poszczególnych domów Polaków mieszkających wśród Ukraińców. Zabraniano zabijania cywilów"16. Cytowany przeze mnie lubelski historyk Grzegorz Motyka zauważa jednak, że te rozkazy w dużym stopniu pozostały tylko na papierze. Partyzanci ukraińscy w latach 1945-1946 przeprowadzili dziesiątki akcji mających na celu zatrzymanie wysiedleń. „Niszczono tory kolejowe, mosty, linie telegraficzne, palono wysiedlone wioski, organizowano zasadzki na oddziały wojska, nie wahano się przed ude-

$\begin{array}{ll}11 & \text { Ibidem, s. } 48 . \\ 12 & \text { Ibidem, s. } 50 . \\ 13 & \text { Ibidem, s. } 54 . \\ 14 & \text { Ibidem, s. } 58 . \\ 15 & \text { Ibidem, s. } 65 . \\ 16 & \text { Ibidem, s. } 66 .\end{array}$ 
rzeniami na wybrane garnizony WP (Wojska Polskiego) i WOP (Wojska Ochrony Pogranicza)"17. Upowcy napadali także na polskie miejscowości, niszcząc je, paląc i zabijając cywilów wbrew rozkazom dowódców, którym zależało na tym, aby działania OUN i UPA były na Zachodzie interpretowane jako posunięcia regularnych oddziałów walczących o niezależność Ukrainy, a nie zwykłych band ${ }^{18}$. Historycy i ukraińscy, i polscy zgadzają się, iż w tym czasie również ludność ukraińska Bieszczad ponosiła krwawe i ciężkie ofiary ${ }^{19}$. Wiosną 1946 akcje przesiedleńcze nasiliły się, a udział wojska był znacznie intensywniejszy. W obliczu dużej przewagi wojska polskiego UPA były bezradne. Sytuacja podziemia ukraińskiego stawała się beznadziejna, a dla nacjonalistów najgorszy był fakt, iż „po zakończeniu w 1946 r. wysiedleń do ZSRR poparcie Ukraińców dla UPA mocno spadło"20. Władze polskie postanowiły zakończyć zwycięsko zmagania z oddziałami UPA podczas akcji „Wisła". Polski historyk nie pisze z triumfem czy z jakąkolwiek satysfakcją o zakończeniu walk, ponieważ przewaga wojsk polskich była tak ogromna, że ich zwycięstwo nie mogło stanowić przyczynku do glorii ${ }^{21}$, z drugiej strony dzieło wysiedlania nie miało też charakteru etycznie błogosławionego. Grzegorz Motyka pisze: „Tak więc w celu zlikwidowaniu kilkuset partyzantów Polska Partia Robotnicza wyrzuciła z od wieków uprawianej ojcowizny bez wahania 35 tys. cywilnych osób"22. Ta liczba dotyczy okresu pierwszych tygodni akcji „Wisła”, w której wywożono z Bieszczad Ukraińców, Bojków i Łemków do USSR lub w różne strony Polski, zwłaszcza na Ziemie Odzyskane. W sumie do końca roku 1950, kiedy to miały miejsce ostatnie wywózki, przesiedlono ponad 130 tys. osób cywilnych ${ }^{23}$. Ofiar w ludziach w wyniku walk bieszczadzkich od roku 1945 do 1948 było po stronie polskiej od 6 do 8 tysięcy, ale niemało, a nawet więcej też było po stronie ukraińskiej ${ }^{24}$. „To prawda — pisze Motyka — iż na Wołyniu cierpieli głównie Polacy, ale w Bieszczadach ofiarami byli wszyscy rdzenni mieszkańcy, niezależnie od narodowości”25.

W filmie Ewy i Czesława Petelskich, analogicznie do powieści Gerharda, na której został oparty scenariusz, występuje nawiązanie do ważnego, głośnego zdarze-

17 Ibidem, s. 68.

18 Ibidem, s. 71.

19 Ibidem, s. 72-73.

20 Ibidem, s. 83.

21 W Bieszczadach znajdowały się wówczas trzy rodzime sotnie UPA: „Bira”, „Chrina” i „Stacha”. Niewykluczone, iż okresowo mogła też pojawić się sotnia „Myrona”. Jak zatem łatwo policzyć, przeciwko trzem-czterem sotniom UPA oraz bojówkom SB i siatki cywilnej (nie więcej niż 500-700 ludzi) skierowano ponad 10 tys. żołnierzy, wspieranych przez MO, WOP, dwa pociągi pancerne i lotnictwo. Dawało to przewagę 1:20 czy nawet 1:25 (której rzekomo wojsko przy zwalczaniu UPA nigdy nie osiągnęło. Ibidem, s. 86.

22 Ibidem.

23 Ibidem, s. 92.

24 Ibidem, s. 43, przypis. 24.

25 Ibidem, s. 94. 
nia militarnego, w którym triumfowali bojowcy UPA — napadu na strażnicę WOP w Jasielu. Upowcy wzięli wówczas 75 jeńców (według danych ukraińskich, bo według polski - $94^{26}$ ). Spośród nich 20 wypuszczono wolno, a 60 rozstrzelano. Z masakry udało się uciec Pawłowi Sudnikowi, który opowiadał, że Ukraińcy kazali jeńcom położyć się twarzą do śniegu i strzelali im w tył głowy. Właśnie motyw ucieczki wykorzystał w Łunach w Bieszczadach Gerhard. W filmie ucieczką od śmierci z rąk upowców salwuje się Kaleń. Inne autentyczne zdarzenie przywołane przez pisarza, a następnie przez Petelskich, to wpadnięcie polskich oddziałów WOP i WP w zasadzkę w rejonie wsi Wysoczany i Kożuszne (w powieści i w filmie pod Smolnikiem) zastawioną przez sotnie „Chrina” i „Myrona”. Polacy wyszli z okrążenia, ale z potężnymi stratami — ponad 30 zabitych i dziewięciu wziętych do niewoli, gdzie zostali straceni. W powieści i w filmie rozprawienie się z jeńcami ma wymiar makabrycznej masakry, ponieważ — jak już pisałem — jeńcom ścina się głowy w podniosłym rytuale przy skandowaniu nazwiska Bandery. Grzegorz Motyka pisze: „Nic nie wskazuje na to, iż zostali ścięci toporem (choć prawdopodobnie siekierą dobito przynajmniej jednego z rannych Polaków)"27. Motyka rozsądnie zauważa, że gdyby taki fakt rytualnego obcinania głów jeńcom miał miejsce, ,gdyby taką zbrodnię oczywiście odkryto, zapewne natychmiast wykorzystano by ją propagandowo" 28 .

Można by zapytać, skąd u Gerharda, który był jednym z dowódców wojsk działających w Bieszczadach w interesującym nas okresie, a więc znał fakty, tudzież w niezłym przecież filmie Petelskich, skądinąd bardzo realistycznym, skąd taka nieścisłość. Zapewne Gerhardowi chodziło o wzmocnienie efektu propagandowego, o zohydzenie nacjonalistów ukraińskich w oczach opinii polskiej. Był jednak w tym jakiś jeszcze inny motyw, jakaś usprawiedliwiona reminiscencja Rzezi Wołyńskiej, o której wszak nie można było w PRL-u mówić czy pisać aż do końca komunizmu, czyli roku 1989. Reminiscencja, powiedzmy, kompensująca choć w symbolicznym wymiarze owo haniebne milczenie. Rzezi, w której ukraińskie siekiery, a także kosy, sierpy, noże, piły i inne narzędzia tnące odegrały rolę bodajże kluczową w ,patriotycznej" robocie banderowców.

Łuny w Bieszczadach Gerharda zawierają bardzo pokaźną listę nieścisłości albo po prostu kłamstw historyczno-politycznych. Przez lata powieść ta uchodziła za dzieło dokumentarne, na co dał się nabrać nawet Norman Davies, który w swoim monumentalnym Bożym igrzysku (książce będącej świetną historią Polski) z 1992 roku polecał tę lekturę jako beletryzowaną relację o wydarzeniach bieszczadzkich godną zaufania (w wydaniu Bożego Igrzyska z roku 2000 nie ma już tej gafy). Przed zorganizowaniem rytualnej zbiorowej dekapitacji polskich żołnierzy upowcy z powieści Gerharda i filmu Petelskich fundują sobie jeszcze inną zabawę. Oto kilkunastu polskich wojaków podczas ucieczki dostało się na pole minowe. Aby widowisko

26 Ibidem, s. 73.

27 Ibidem, s. 74.

28 Ibidem, s. 21. 
ich śmierci uczynić atrakcyjniejszym, szef oddziału (wg powieści „Ren”, w filmie „Bir” grany znakomicie wprost przez Leona Niemczyka) nakazuje swoim strzelanie pod nogi Polakom, którzy w ten sposób zostali zmuszeni do tańca. Zapewne harmonizował ów motyw w okresie powstawania powieści i filmu, a i nadal często harmonizuje z odczuciami Polaków wobec Ukraińców, zwłaszcza kojarzonych z faszystami ukraińskimi i z tym, czego dokonywali na Wołyniu, Podolu i Pokuciu w latach 1942-1944, ale przecież jako element sekwencji zdarzeń bieszczadzkich był zmyślony.

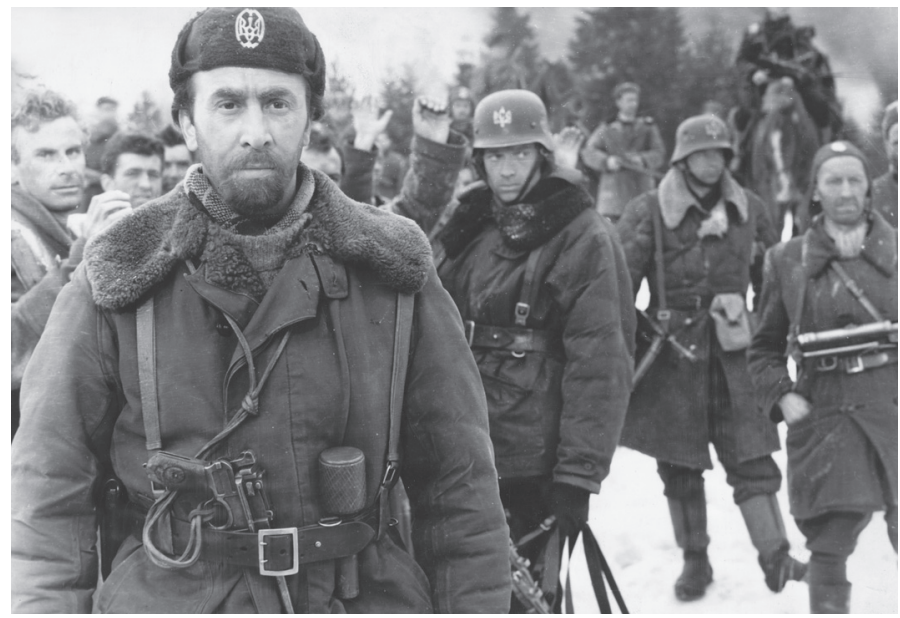

2. Sotenny „Bir” grany przez Leona Niemczyka. Ogniomistrz Kaleń, reż. Ewa i Czesław Petelscy, 1961, ze zbiorów Muzeum Kinematografii w Łodzi

Chociaż pewna inspiracja autentyczna, historyczna istniała. Oto bowiem upowcy zakładali przecież pułapki minowe wiosną i latem 1946 toku, a w jednej z takich pułapek 8 czerwca 1946 roku zginęło 12 przesiedleńców i jeden żołnierz. Powieść Gerharda, w porównaniu z filmem, sugeruje o wiele więcej win bieszczadzkich oddziałów UPA. Wynika z niej na przykład, że upowcy likwidowali wszystkich polskich żołnierzy, a wszakże istnieją świadectwa zaprzeczające tej tezie ${ }^{29}$. Zarówno Gerhard, jak i Petelscy pomijają wstydliwą kwestię prześladowań ludności ukraińskiej przez polską milicję czy polskie wojsko. Albo sprawę nadużyć dokonywanych przez Wojsko Polskie, kradzieże czy wymuszenia pieniędzy ${ }^{30}$.

Zarówno Gerhard, jak i Petelscy traktują z analogiczną niechęcią partyzantów ukraińskich, jak i partyzantów polskich z oddziałów Armii Krajowej, sugerując też,

29 Ibidem, s. 22.

30 Ibidem, s. 23. 
że obydwie organizacje podziemne — polska i ukraińska — współdziałały ze sobą $\mathrm{w}$ walce z komunistyczną władzą w Polsce.

Wbrew temu, co napisał Gerhard, w Bieszczadach nie doszło do ścisłej współpracy polskiego i ukraińskiego podziemia (nie mówiąc już o rzekomych wspólnych akcjach przeciwko wojsku, jak to zostało pokazane w filmie Ogniomistrz Kaleń, gdzie w scenach zajmowania stanowisk ogniowych wokół kompanii Wierzbickiego obok upowców wchodzą na pozycje resztki oddziału Żubryda) ${ }^{31}$.

W sposób haniebnie fałszujący i krzywdzący został w powieści, jak i w filmie, sportretowany Antoni Żubryd (w filmie grany przez Janusza Kłosińskiego). Jest to typ przedwojennego, trochę ograniczonego kaprala, który bez ceregieli rozprawia się z Bogu ducha winnym żołnierzykiem LWP, nie ma skrupułów przy torturowaniu Polaków (tu: Kalenia).

Żubryd — czytamy w książce Motyki — jeden z bohaterów powojennego podziemia, pod piórem Gerharda zamienia się w postać straszną i żałosną zarazem. Cechują go wielkie ambicje w żaden sposób nieprzystające do intelektualnych możliwości. Nie potrafi nawet sprawnie dowodzić oddziałem, bezkarność zawdzięczając słabości władzy ludowej ${ }^{32}$.

W powieści dodatkowo cechuje go obsesyjny antysemityzm (w filmie nie ma tego wątku!), co widać, kiedy raduje mu się twarz po zabiciu przez jego żołnierzy, nieustępujących notabene w okrucieństwie upowcom ${ }^{33}$, żydowskiego małżeństwa Wasserów. Niechęć Gerharda i — niestety — też Petelskich do Żubryda oraz formacji akowskich reprezentowanych przez niego oddają słowa byłego ziemianina Dwernickiego (świetnie granego przez Janusza Strachockiego), które wykrzykuje pod adresem Żubryda w czasie walki o posterunek milicji w Hoczwi:

Hultaju, pachołku, bezprawnie tytułujący się majorem! (...) poznałem cię po tym pijackim głosie, psi synu, bandyto spod ciemnej gwiazdy, kłamco i oszuście. Podejdź no tu bliżej, łajdaku! (...) tchórzliwy zbrodniarzu, morderco kobiet i dzieci, gwałcicielu, rezunie, tępy analfabeto! ${ }^{34}$

W filmie te inwektywy przytoczone są niemal bez jakiejkolwiek zmiany. Tymczasem biografia Antoniego Żubryda całkowicie przeczy tej nienawistnej charak-

31 Ibidem, s. 28. G. Motyka zauważa jednak, że poza Bieszczadami doszło kilkakrotnie do współpracy między polskimi i ukraińskimi oddziałami podziemnych wojsk. Na przykład na Lubelszczyźnie, gdzie przeprowadzone zostały dwie akcje zbrojne przez Polaków z AK i Ukraińców z UPA.

32 Ibidem, s. 29.

33 Bez najmniejszych skrupułów wieszają robotników z kopalni ropy związanych z PPR, a litości nie przejawiają także wobec własnych kolegów z oddziału — jeśli są ranni, zarąbują ich siekierami, aby nie wpadli w ręce LWP. Gerhard, zaiste, swoją ideologiczną nienawiść do wrogów komunizmu wylał w Łunach w Bieszczadach w barokowym nadmiarze: działacze PSL (Polskiego Stronnictwa Ludowego - jedynej partii sprzed wojny, której komuniści zezwalali na funkcjonowanie) są w powieści sojusznikami „bandytów” (na 583 strony powieści aż 107 poświęcono „polskiej reakcji”), sfałszowane referendum z roku 1946 „sfałszował” po raz drugi, jak również wybory do sejmu w styczniu 1947. Itd., itd.

34 J. Gerhard, Łuny w Bieszczadach, Lublin 1977, s. 172. 
terystyce. Ukończył szkołę podoficerską, we wrześniu w stopniu plutonowego brał udział w obronie Warszawy. Był więziony przez NKWD, potem przez hitlerowców, skazany przez tych ostatnich na karę śmierci, której uniknął, gdyż udało mu się zbiec z miejsca egzekucji. Po wkroczeniu Sowietów w 1944 roku został przyjęty do służby w sanockim UB, ale potem - w czerwcu 1945 roku — przeszedł do podziemia, „stając na czele jednej z licznych niewielkich grup zbrojnych działających w tym czasie na Podkarpaciu" ${ }^{35}$. Wkrótce stworzył stuosobowe zgrupowanie poakowskie, o którym sami komuniści mówili, że jest dobrze zorganizowane i trzymane twardą ręką przez Żubryda ${ }^{36}$. Trudy życia partyzanckiego zdecydowała się dzielić z Żubrydem jego żona Janina, która — aby to uczynić — pozostawiła roczne dziecko pod opieką babci ${ }^{37}$.

Oddział Żubryda organizował zasadzki na wozy przewożące pieniądze, na grupy UB (Urzędu Bezpieczeństwa), MO (Milicji Obywatelskiej) i WP (Wojska Polskiego), na pojedynczych reprezentantów tych jednostek, likwidując ich. Jego akcje były skuteczne, dobrze zorganizowane, a nieraz brawurowe. Bywało jednak tak, że niektóre akcje ocierały się o zwykłe rabunki, a historycy do dziś mają kłopot ze sformułowaniem pełnej spójnej charakterystyki Żubryda (to przecież znany temat psychologiczno-socjologiczny: degenerowanie się nawet najlepszych żołnierzy i oficerów w sytuacji zakończenia głównych działań wojennych, kiedy nadal zmuszeni są prowadzić działania partyzanckie). Na niekorzyść żubrydowców i innych oddziałów partyzantki akowskiej działał również fakt, iż w Bieszczadach — jak to po wojnie - funkcjonowały liczne zwykłe bandy, które niejednokrotnie podawały się w swoich działaniach bandyckich za żołnierzy AK. Dlatego często jest niezwykle trudno ocenić, czy dany napad rabunkowy był dziełem partyzantów, czy zwykłych bandytów ${ }^{38}$. Z analiz Grzegorza Motyki, z poważnych lektur, na które się powołuje ten autor w swojej świetnej książce, jasno wynika, że Żubryd i jego ludzie nie byli zamieszani w działania antysemickie. Jeśli nawet mogli mieć coś wspólnego z zabójstwem małżeństwa Propperów w Sanoku (do którego Gerhard zdaje się nawiązywać w motywie egzekucji na małżeństwie Wasserów), to z racji uwikłania Propperów we współpracę z PPR ${ }^{39}$. Żubrydowcy nie byli aniołami, jak nie są nimi żadni żołnierze wyklęci we wszelkich częściach świata, ale mieli ogromne poparcie ludności polskiej w Bieszczadach, zwłaszcza inteligencji, a w tym uczniów sanockiego liceum ${ }^{40}$. Żubryd, jak na romantycznego dowódcę żołnierzy wyklętych przy-

35 G. Motyka, op. cit., s. 97.

36 Ibidem, s. 98.

37 W filmie ten motyw został przesunięty na stronę ukraińską: sotenny (dowódca sotni, czyli batalionu) Bir (grany przez Leona Niemczyka) ma przy sobie cały czas żonę z małym dzieckiem).

38 G. Motyka, op. cit., s. 105.

39 Ibidem, s. 110-111. PPR to znienawidzona przed wojną jeszcze działająca promoskiewska komórka partii komunistycznej.

40 Ibidem, s. 113. 
stało, był nieuchwytny. Ale nie wiedział, że ma pośród swoich żołnierzy Judasza - agenta komunistycznej UB. Ten zabił go i jego żonę Janinę. Proces zabójcy Antoniego Żubryda odbył się dopiero w roku 1999, podczas którego Jacek Vaulin tak bowiem nazywał się siepacz komunistyczny — zeznał, że zlikwidował małżeństwo Żubrydów, bojąc się demaskacji, która od jakiegoś czasu mu groziła, a więc niejako w obronie własnej, a nie z rozkazu resortu bezpieczeństwa. Sąd uwierzył mu i umorzył sprawę $e^{41}$. Wcześniej jeszcze — w 1994 roku — sąd w Rzeszowie uznał, że Żubryd działał na rzecz niepodległości Polski.

\section{ZERWANY MOST (1962)}

Choć to PRL-owski film wojenny, ale przecież trzeba jasno to powiedzieć, że znakomity. Znakomity film przygodowy, oparty na dłuższym opowiadaniu Romana Bratnego pt. Śniegi ptyna (1961), ze świetnie uformowanym zarysem/profilem westernowym, niepozbawiony prawdy psychologicznej, socjologicznej i kulturowej. Zwłaszcza dzięki grze aktorskiej Tadeusza Łomnickiego, wcielającego się w główną postać filmu - porucznika i inżyniera Mosura, wykonawcy wyroku na ostatnim upowskim watażce/prowidnyku. Rzecz dzieje się w Bieszczadach, w dwu planach czasowych — teraźniejszym, tuż po wojnie, kiedy Mosur przyjeżdża w góry do pra-

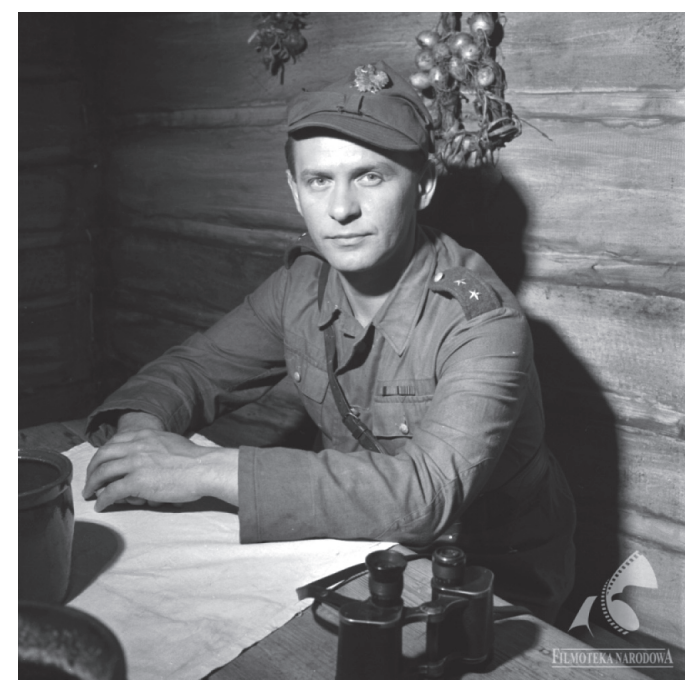

3. Tadeusz Łomnicki jako porucznik/inżynier Mosur. Zerwany most, reż. Jerzy Passendorfer, 1962, Filmoteka Narodowa

41 Ibidem, s. 120. 
cy jako inżynier, i przeszłym, kiedy działa w Bieszczadach jako żołnierz Ludowego Wojska Polskiego walczącego z oddziałami UPA. Dostaje wówczas do wykonania niezwykle trudne zadanie, jak z dobrego scenariusza sensacyjno-szpiegowskiego czy też westernowego. Ponieważ zna doskonale język ukraiński, ukraińskie obyczaje, strukturę i sposoby działania upowców, ma dostać się w ich szeregi jako wysłannik działaczy UPA z Zachodu, wziąć udział w brutalnych akcjach przeciwko żołnierzom polskim, by całkowicie uśpić czujność banderowców, aby potem zlikwidować ich dowódcę, wspomnianego ostatniego prowidnyka (granego przez Mieczysława Voita) i tym samym przyczynić się do całkowitego zakończenia działań wojennych. Toż to temat klasycznego filmu sensacyjno-przygodowo-westernowego! Zadanie zostaje wykonane, ta część akcji jest zaiste poprowadzona mistrzowsko jak na polski film wojenno-przygodowy, ale po wojnie, kiedy porucznik przyjeżdża do Bieszczad jako inżynier, zostaje oskarżony o współpracę z UPA. Na szczęście ocalałe dokumenty ratują mu życie i honor.

Piękny film, wcale nienajeżony ideologią komunistyczną, nieukazujący upowców jako potworów, uniwersalny w swojej wymowie, w której epicentrum jest piękna, bohaterska, mężna, a przy tym pozbawiona zadęcia i bohaterszczyzny postawa - chciałoby się powiedzieć — prostego inżyniera. Również oparcie w rzeczywistości fabuła filmu Passendorfera miała solidne, albowiem Bratny nawiązał do działalności utworzonego przez Urząd Bezpieczeństwa pozorowanego oddziału UPA, którego celem miała być likwidacja przywódcy OUN w Polsce. Z tym, że W rzeczywistości zamiar ten nie powiódł się. Jak na ironię, można by przyznać, finał podjętych działań agenturalnych porucznika Mosura został zainspirowany innym autentycznym spiskiem, o którym już wspominałem, mianowicie — udanym zabójstwem na zlecenie UB Antoniego Żubryda i jego żony przez wtyczkę ubowską $\mathrm{w}$ jego oddziale. Jak na ironię, bo oto $\mathrm{w}$ rzeczywistości polskim komunistom nie udało się zlikwidować ukraińskiego nacjonalisty, ale za to z powodzeniem usunęli dzielnego polskiego wojaka.

Grzegorz Motyka pisze w swojej książce o Łunach w Bieszczadach i o relacji świata tej powieści do rzeczywistości polityczno-historycznej, o tym, że oddziałała ona swoją fałszującą bryzą kłamstw na wielu autorów, nie tylko pisarzy, lecz także historyków sięgających do tematu walk bieszczadzkich. Bratnego też owionęła ta trująca bryza. Pojawia się oto w jego fabule (w filmie tego nie ma) ,motyw wciągniętej w zasadzkę i zmasakrowanej kompanii WP (jeńców oczywiście ścięto toporem), a także napadu na transport chorych i rannych, którzy zostają dobici bagnetami" ${ }^{42}$. Żadna relacja historyczna — polska czy ukraińska — nie potwierdza takiego zdarzenia. Jerzy Passendorfer pominął ten fałszywy powieściowy motyw w swoim filmie, tak jak pominął pogardliwe nieco odniesienie się głównego bohatera do Ukraińców. Mosur taki oto ma stosunek do języka ukraińskiego: „Ech, szczob tebe maty ne rodiła

42 Ibidem, s. 33. 
— żalił się sobie po ukraińsku. Lubił ten język, jak dalekie, mroczne i dzikie pieśni pastuchów" ${ }^{43}$. Nie ma w utworze Passendorfera tego postkolonialnego elementu, choć przecież trzeba przyznać, że usprawiedliwionego, zważywszy na cywilizacyjne zapóźnienie Rusinów/Ukraińców w stosunku do Rzeczypospolitej czy Rosji w wiekach dawnych. Inna sprawa - oczywiście! — że owo zapóźnienie, ów efekt mniejszego ucywilizowania czy nawet zdziczenia czy dzikości Rusinów (widoczny choćby w pierwszym eposie Rusińskim, jakim był Taras Bulba Mikołaja Gogola), a więc owo „zdziczenie” było bardziej zawinione przez Polaków i Rosjan, przez wieki eksploatujących Ukraińców, wykorzystujących ich jako mięso armatnie w różnych wojnach, by potem odpłacać pięknym za nadobne, bardziej niż przez samych Ukraińców.

Aliści polski reżyser oddał jednak honor owej może niemiłej, ale romantycznej, Ukraińcom prawdzie, prawdzie o pewnym barbarzyńskim nachyleniu mentalności ich nacjonalistów w pięknej scenie między porucznikiem Mosurem i Wierą (graną przez Lidię Korsakównę), członkinią grupy Krwawego Wasyla. Nachyleniu jeszcze rodem z Siczy, opisywanej i romantyzowanej przez Mikołaja Gogola w Tarasie Bulbie, a potem naśladowanej w prezentacji czerni Rusińskiej i Siczy też przez Sienkiewicza w Ogniem i mieczem. Do Siczy, jak wiadomo, kobiety prawa wejścia nie miały. Była to przestrzeń wrzącego, pieniącego się testosteronu. Kobiety w tym świecie nie mają żadnych praw prócz rodzenia i służenia swoimi wdziękami sokołom ukraińskim. Stary Bulba zabija syna tyleż za jego zdradę na rzecz Polski, ile za stratę rozumu przez kobietę. Sienkiewicz, który jak się rzekło, najsilniej wzorował się w odmalowywaniu duszy kozaczej na Gogolu, przedstawiał przystojnego Bohuna jako człeka przez Helenę Kurcewiczównę nawróconego na ludzkie drogi, skoro po prostu po jej porwaniu nie zgwałcił jej i nie zmusił do ślubu przed popem. Wcześniej przecież nieraz bywało, jak czytamy w Ogniem i mieczem, że dzielny Kozak i jego kompani pohulali dziarsko z dziewczętami, a potem kamień im do szyi i w Dniepr. Otóż porucznik Mosur zdaje się przyciągać Wierę swoją pewną innością, jest jakby delikatniejszy, subtelniejszy od jej leśnych kamratów. Dziewczyna chodzi za nim, patrzy mu w oczy. I nagle ten subtelniaczek przemawia do niej jak siczowy sokił, modelując przy tym wspaniale głos, tak że nie ma wątpliwości, że Mosur jest rodowitym Ukraińcem. Dialog w tej scenie toczy się, oczywiście, po ukraińsku: ,Ty znowu za mną łazisz?". Podchodzi do niej z pistoletem luźno trzymanym w dłoni. Nagle obraca się w jej kierunku i łapie za kołnierz: „Czego chcesz ode mnie?! — te słowa wypowiada groźnie. Piękna Korsakówna, patrząc w oczy Łomnickiemu, uśmiecha się i mówi z przekąsem: „Oj, jakiś ty głupi!” Mosur z ironicznym uśmiechem cofa się i zaprasza do siebie dziewczynę, która rusza w jego kierunku, ale kiedy ten mówi „Chodź ze mną w krzaki” i diabelsko śmieje się na cały las, piękna

43 R. Bratny, Śniegi plyną. Szczęśliwi torturowani. Brulion. Ciagle wczoraj, Kraków-Warszawa 1985, s. 101. 
Ukrainka przeżywa upokorzenie. Nic bardziej nie przekonałoby jej o tym, że Mosur jest banderowskim sokiłem niż takie właśnie jego rezunowe zachowanie.

A oto scena z początku Tarasa Bulby, w której stary Ukrainiec poucza syna, który powrócił z nauk w Kijowie, jaki ma mieć stosunek do matki i w ogóle do kobiet:

— Ejże, widzę, że z ciebie chyba maminsynek - mówił Bulba. — Nie słuchaj, synku, matki, ona baba. Niczego ona nie wie. Jaka z wami może być pieszczota? Wasza pieszczota to szerokie pole i dobry koń, rozumiecie? A widzicie tę szablę — ona waszą jest matką! ${ }^{44}$

Dodajmy jednak, że w tym tak udatnym pozorowaniu przez Łomnickiego behawioru kozackiego, a także rys powagi, pewnej grozy i mroczności bijący z postaci prowidnyka „Krwawego Wasyla” odgrywanego przez Mieczysława Voita, a również prowidnyka „Bira” w Ogniomistrzu Kaleniu granego przez Niemczyka, że jest w tym oddany przez Passendorfera i Petelskich respekt dla sprawy ukraińskiej, która nie jest $\mathrm{w}$ ich filmie interesem leśnych band rezunów, lecz leśnych oddziałów partyzanckich walczących z determinacją i energią o sprawę już przegraną, ale politycznie niepozbawioną słuszności.

\section{WILCZE ECHA (1968)}

Utwór Aleksandra Ścibora-Rylskiego (wcześniej scenarzysty Polskiej Szkoły Filmowej) to film przygodowy, nakręcony od początku do końca, i trzeba przyznać, że z pewnym powodzeniem, w konwencji westernowej, którego akcja toczy się w Bieszczadach, kilka lat po II wojnie światowej. Reżyser tak zapowiadał swój film, przystępując do jego realizacji:

Pierwsze lata po wojnie były trudne, ale dla literatury i dla filmu wyjątkowo bogate: pełne dramatyzmu, niebezpieczeństw, a także przygód. Być może, iż z czasem, gdy najbardziej bolesne wspomnienia przygasną i wyblakną, okres ten stanie się dla naszego filmu taką samą kopalnią tematów, jaką dla Amerykanów stał się pionierski okres ,zdobywania Zachodu”. Wiadomo, że i wtedy działo się tam wiele rzeczy znacznie poważniejszych niż pojedynki sprawnych rewolwerowców, ale do tradycji literackiej i filmowej wszedł właśnie człowiek z koltem, jako idealny wyraziciel atmosfery owych lat. Przyjmując w warstwie fabularnej poetykę klasycznego filmu kowbojskiego, będę równocześnie próbował położyć nacisk na polskie realia ${ }^{45}$.

Bieszczady, jak wiemy, jeszcze w trzy lata po wojnie były areną tragicznych i krwawych wydarzeń. Realizatorzy filmu, odwołując się do autentycznych zdarzeń odnotowanych w protokołach z bieszczadzkich posterunków milicyjnych, na plan pierwszy wysunęli przygodę: ucieczki i pogonie, pojedynki, sprytne pułapki i cudowne ocalenia, i oczywiście — miłość do pięknej dziewczyny, która pomaga bohaterowi w walce o sprawiedliwość. W centrum zaś stoi postać idealnego westmana

44 M. Gogol, Taras Bulba, przeł. A. Ziemny, Warszawa 2002, s. 12-13.

45 A. Ścibor-Rylski, Rozmowa z B. Janicka, „Kino” 1967, nr 10. 
(choć raczej trzeba by napisać easternmana), który choć nieco nicpoń, niepozbawiony grzeszków i nadmiaru indywidualizmu, jest człowiekiem wyjątkowo prawym. Jest nim chorąży Słotwina, grany przez estońskiego przystojniaka - Brunona O'Yę. To wprawdzie świetny wopista (żołnierz ochrony pogranicza), znakomity tropiciel przemytników i innych ciemnych elementów operujących przygranicznie, ale nieustannie narusza międzynarodowe regulaminy, za co zostaje przeniesiony do cywila. Ale właśnie w drodze do owego cywila, jadąc na pięknym koniu z pistoletem przy pasie, natyka się na grupę skorumpowanych komunistycznych milicjantów, a właściwie bandytów.

Jest rok 1948. W zrujnowanej, wyludnionej Derenicy koczują niedobitki okolicznych mieszkańców. Porządku pilnują nieliczne posterunki WOP-u. Do tego właśnie miasteczka przybywa zwolniony ze służby za brak dyscypliny chorąży Słotwina, dawny uczestnik walk z bandami. Doskonale zna okolicę i ludzi, więc szybko się domyśla, że w Derenicy źle się dzieje. Posterunek MO, dowodzony dawniej przez jego przyjaciela Władeczka, stał się zakonspirowaną meliną grupy Moronia, groźnego bandyty. Pracująca w komendzie Tekla kontaktuje Słotwinę ze swoim chłopakiem Witoldem, jedynym z ludzi Władeczka, który ocalał z pogromu posterunku. Witold ukrywa się przed Moroniem, oskarżony o niepopełnione przestępstwo. Słotwina postanawia rozprawić się z bandą. Domyśla się, że Moroń chce zdobyć skarb Tryzuba, czyli pieniądze i kosztowności sotni UPA zrabowane polskiej ludności cywilnej ukryte w jednym z bunkrów na tym terenie. Odnalezie-

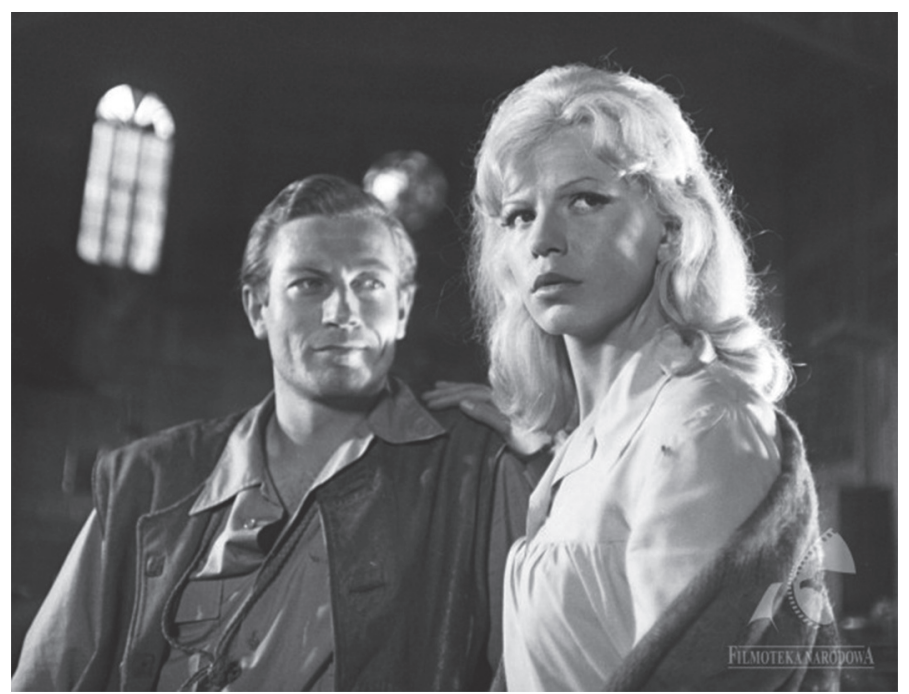

4. Irena Karel jako Tekla i Bruno O’Ya jako Słotwina. Wilcze echa, reż. Aleksander Ścibior-Rylski, 1967. Fot. Janusz Zachwajewski, CSF KADR, SF TOR, SF ZEBRA. Filmoteka Narodowa. Licencja: SF KADR 
nie skarbu jednocześnie przynosi rozwiązanie zagadki śmierci Władeczka i jego ludzi. Odwaga, inteligencja, spryt i dobra wola Słotwiny, w połączeniu z dobrą wolą pięknej blondynki Tekli (Irena Karel) oraz poczciwością muskularnego Aldka (Marek Perepeczko), który z bandyckiej grupy przechodzi za sprawą pedagogicznych manewrów na stronę „,szeryfa” Słotwiny - wszystkie te atuty doprowadzają do optymistycznego końca: skarby wracają na łono społeczeństwa, a bandyci podszywający się pod milicję ludową zostają aresztowani.

Obraz Ścibora-Rylskiego stanowi, w istocie, do dzisiaj widowisko sympatyczne, dobrze się oglądające, tak jak dobrze się ogląda wszelkie sprawnie zrealizowane czy westerny, czy filmy sensacyjno-przygodowe, w których sympatyczny bohater walczy skutecznie o sprawiedliwość, zaświadcza o istnieniu najwyższych wartości i na koniec zostaje nagrodzony piękną dziewczyną. Problem jednak w tym, że Bieszczady w krótkiej polskiej historii PRL-owskiej (film powstawał w latach 1967-1968) były miejscem, w którym straszyły duchy, pełno było trupów w szafie, a tymczasem na ekranie niczego takiego nie widać. Dlatego Tadeusz Lubelski po latach napisał o tym filmie: „Nie zadbano jednak o jakiekolwiek uwiarygodnienie skomplikowanej materii fabularnej, którą był realny konflikt na polsko-ukraińskim pograniczu" 46 . Wprawdzie Ścibor-Rylski zapowiadał film rozrywkowy, „dla widzów”47, ale kiedy się zważy ciężar spraw dzielących Polaków i Ukraińców po drugiej wojnie światowej, spraw nigdy niewyjaśnianych, nieeksplorowanych w PRL-u, to film Wilcze echa wydaje się kompromitujący — dla reżysera, dla producentów, dla władz kinematografii PRL-u w tamtym czasie. Film ten, jak celnie zauważa Rafał Marszałek: „Pokazuje (...), jak zawodna bywa kalkulacja, że wszystko w każdym czasie można pomieścić w kręgu zabawowym"48. Można było mieć wrażenie na początku lat 60 ., że niepokojący Ogniomistrz Kaleń, a również Zerwany most stanowią coś jakby zerwanie milczenia na temat trudnych kwestii polsko-ukraińskich. „Tak się nie stało — konstatuje Marszałek. - Uznano, że łuny w Bieszczadach wygasły już dawno, konflikty nadgraniczne lat 1945-1946 tak bardzo spowszedniały w powszechnym odczuciu, iż mogą być kanwą młodzieżowej baśni przygodowej”49. Innymi słowy, można było już, w założeniach twórców Wilczych ech, mitologizować przestrzeń i historię Bieszczad jako locii belli. A nie można było, bo jak już pisałem, nic nie było z tej historii rzetelnie przerobione. Rzetelnie, czyli uczciwie, szczerze, przez własne doświadczenia i emocje, które wszak tworzą podstawę mityzacji i uświęcenia. Sięgnijmy ponownie do mądrej lektury Marszałka:

Wiedza o konfliktach wschodniego pogranicza nie była u nas własnością ogółu ani nawet większości społeczeństwa. Nurt wspomnieniowo-pamiętnikarski poza znaną relacją Jana Gerharda rozwijał się słabo. O wysiłku zbrojnym mówiły tylko pojedyncze wydawnictwa spe-

46 T. Lubelski, Historia kina polskiego, Videograf II, Chorzów 2008, s. 279.

47 Zob. R. Marszałek, Film fabularny, [w:] Historia filmu polskiego, t. 6, Warszawa 1994, s. 85.

48 Ibidem.

49 Ibidem. 
cjalistyczne; tło polityczne zdarzeń odmalowywane ze schematyczną zdawkowością, właściwą niektórym obchodom rocznicowym. Co najważniejsze zaś, owa problematyka przez długie lata pozostawała poza matrycą edukacyjną. Kolejne generacje Polaków opuszczały szkołę bez wystarczającego rozeznania o sprawie ukraińskiej — tak też było w okresie realizacji Wilczych ech. Zamienić tę nieświadomość na rozrywkową beztroskę znaczyło po prostu utrwalić bylejakość 50 .

A oto dwa główne motywy związane z relacjami polsko-ukraińskimi występujące w filmie i potraktowane właśnie byle jak i utrwalające bylejakość:

1. Narracja wstępna spoza kadru wprowadzająca, na wzór niektórych westernów Johna Forda, widza w miejsce i czas akcji, a przy tym żałośnie wręcz upraszczająca historycznie i ideologicznie:

Bieszczady. Najdalej na południowy wschód wysunięty zakątek Rzeczypospolitej. Wojna trwała tu trzy lata dłużej niż w całej Europie. Przez te trzy lata bandy nacjonalistów spod znaku UPA paliły wsie i miasteczka, wycinając w pień okoliczną ludność. Walka z nimi była długa i krwawa. Kiedy wreszcie umilkły strzały, Ziemia Bieszczadzka przypominała pustynię. Trzeba było jeszcze wielu dalszych lat, aby sprawiedliwość i prawo mogły na stałe powrócić w te strony.

2. Skarb, który stanowi oczko w głowie działań bandytów podszywających się pod milicjantów, to oczywiście drogocenne przedmioty, zwłaszcza biżuteria, polskiej ludności grabionej przez UPA i potem przechowywane w ukryciu. Nie ma w filmie mowy o podobnych krzywdach dokonywanych przez polskich żołnierzy na mieszkańcach ukraińskich Bieszczadów.

\section{PAN WOŁODYJOWSKI (1969)}

Ten piękny epicki obraz, jedno z polskich arcydzieł historycznej epiki przygody autorstwa Jerzego Hoffmana, powstał jako pierwsza część realizacji wielkiego pomysłu polskiego reżysera dotyczącego sfilmowania całej Trylogii Henryka Sienkiewicza (Ogniem i mieczem, Potop, Pan Wołodyjowski ${ }^{51}$ ). Trylogii, która w historii polskiej kultury, polskiego ducha, polskiej mentalności odegrała rolę ogromną. Jest w niej wiele motywów ukraińskich, ponieważ Sienkiewicz opisywał czasy, w których relacje polsko-ukraińskie były żywe i... bardzo różne. Pozytywne i negatywne, z przewagą, niestety, tych drugich. I przeważnie — ponownie niestety — z winy polskiej. Nad czym polski pisarz, a potem ekranizator jego epiki — Jerzy Hoffman - ubolewali. Marzeniem Sienkiewicza, co widać z tonu narracji Pana Wołodyjowskiego, a zwłaszcza Ogniem i mieczem, była pokojowa integracja obu zwaśnionych narodów. O tym marzyły liczne wielkie polskie umysły, m.in. Józef Piłsudski, próbujące znaleźć w sojuszu z Ukrainą antidotum na wampiryczne zakusy Moskwy. Podobnym marzeniem kieruje się od czasu do czasu, kiedy zwraca się ku tematowi polsko-ukraińskiemu, w swojej pracy twórczej Jerzy Hoffman, m.in. autor czteroczęściowego monumental-

50 Ibidem, s. 86.

51 Kolejność wydań poszczególnych tomów: 1884, 1886, 1888. 
nego filmu dokumentalnego o Ukrainie pt. Ukraina. Narodziny narodu (2008). Szerzej o tych ukraińskich sympatiach okazywanych już w wolnej Polsce przez świetnego polskiego reżysera będzie mowa w innym tekście niniejszego tomu, ja ograniczę się tylko do skomentowania pod kątem ,ukraińskości” Pana Wołodyjowskiego.

Powieść o Małym Rycerzu stanowi ostatnią część trylogii Sienkiewiczowskiej, natomiast Hoffman zrealizował ją jako pierwszą. Kiedy powstawał ten film, Hoffman, choć zawsze sympatyzujący z ukraińską i rosyjską kulturą (spędził dzieciństwo na Syberii, co wcale nie zohydziło mu ojczyzny Tołstoja, tak jak to też było w przypadku poety Lucjana Szenwalda, który pisał piękne wiersze o Syberii, a Czesław Miłosz sardonicznie, ale szczerze przyznawał, że to najlepsze polskie wiersze o tej części świata). Poza tym ojciec reżysera był oficerem wojska polskiego utworzonego w ZSRR. Inna wielka siła pchająca Hoffmana w przepastne ramiona miłości do Rosji i Ukrainy to ukraińska piękność - Walentyna, druga żona reżysera, największa kobieca muza jego życia. Jej wpływ na eskalację pasji ukraińskiej, a właściwie polsko-ukraińskiej Hoffmana, był niebotyczny. „Wiele propozycji obsadowych w moich filmach - mówił reżyser — było jej pomysłami: wymyśliła m.in. Magdę Zawadzką do roli Baśki" 52 .

Akcja Pana Wołodyjowskiego, jak i pozostałych części Trylogii, łączy dramatyczne przygody miłosno-heroiczne/militarne tytułowego protagonisty z przygodami ojczyzny. Jest to czas bezkrólewia po sejmie abdykacyjnym, na którym Jan Kazimierz zrezygnował z korony. Podczas szóstej z kolei elekcji wybrano potomka słynnego magnata Jeremiego Wiśniowieckiego - Michała Korybuta Wiśniowieckiego, który w kategoriach władczo-żołnierskich był zaprzeczeniem swego sławnego rodzica. Był wykształcony i obyty w świecie, ale pozbawiony charakteru. Nie mógł zatem przeciwstawić się prywacie magnackiej, która dawała o sobie coraz częściej znać w Rzeczypospolitej. Jej ofiarą stawał się też pomysł co światlejszych umysłów polskich, aby dążyć do zrównania Polaków w prawach z Rusinami. Te niepokoje Sienkiewicz ukazał, zasugerował. Ze spraw zewnętrznej polityki pisarz zauważa okoliczność taką oto, iż niewielka część zachodniej Ukrainy, która pozostała przy Rzeczypospolitej po powstaniu Chmielnickiego, była niepokojona przez Turków, m.in. za sprawą przywódcy prawobrzeżnych Kozaków - Piotra Doroszenki, który nie mogąc porozumieć się z Polakami, szukał aliansu z Turkami i Tatarami. Efektem tego było zagrożenie Rzeczypospolitej ze strony tych trzech potęg w roku 1671. Udało się je zastopować hetmanowi koronnemu Janowi Sobieskiemu, przyszłemu królowi Polski. Wojnę z Turkami Sienkiewicz przedstawił dość wiernie, włącznie z obroną Kamieńca Podolskiego i jego wysadzeniem w powietrze. Wołodyjowski, zanim objął dowództwo nad tą twierdzą, sprawuje komendę nad stanicą w Chreptiowie nad granicą mołdawską, gdzie ma za zadanie pilnować wschodnich granic Rzeczypospolitej, dybiąc

52 Wywiad z Jerzym Hoffmanem: „Gala” 2010, nr 27, http://kobieta.onet.pl/uroda/gwiazdy/jerzy-hoffman/jtk37. 
na Tatarów czy Turków albo niegrzecznych Kozaków zapuszczających się na tereny Rzeczypospolitej i łupiąc ją, tudzież sprawdzając jej wrażliwość ${ }^{53}$.

Zwróćmy jednak uwagę na istotę rzeczy — odniesienia pisarza do Rusinów. Wspomniana postać rokoszanina Doroszenki jest tylko wzmiankowana w powieści. U Wołodyjowskiego w Chreptiowie znajduje się oddział Semenów (jazdy kozackiej) dowodzony przez niejakiego Motowidłę. Ten motyw wskazuje na historyczną oczywistość - Rusini/Ukraińcy przez wieki byli podzieleni, jeśli chodzi o swój stosunek do Rzeczypospolitej, co było świadectwem słabo jeszcze w XVII wieku uformowanej samoświadomości, tożsamości narodowej potomków wojowników i władców dawnej Rusi Kijowskiej. Oprócz tych motywów są inne trzy akcenty wyjątkowo wzruszające w kontekście naszych poszukiwań tonów nawoływań do zgody i pojednania między Polakami i Ukraińcami:

1. Wiele stron powieści zajmuje dramatyczne i poruszające opowiadanie szlachcica Muszalskiego o wzajemnej nienawiści jego jako Polaka do sąsiada Ukraińca - Dydiuka - nienawiści, która nieoczekiwanie przechodzi, pod wpływem wspólnych doświadczeń niedoli, cierpień w niewoli osmańskiej, w prawdziwą, głęboką zażyłość. Oprócz samej historii nienawiści i miłości obu junaków pełno jest w opowieści Muszalskiego fascynacji światem kozackim, Siczą, fantazją zaporoską, normalnie — jak w całej trylogii Sienkiewicza.

2. Azja, syn Tuhajbeja, chce nakłonić hetmana Sobieskiego, aby zgodził się na układ z Tatarami, którzy działaliby pod jego — Azji — przywództwem przeciw Kozakom. Wysyła do hetmana swego posła. Sobieski twardo odmawia, argumentując przede wszystkim stwierdzeniem, iż Polacy i Ukraińcy są braćmi w wierze i hańbą byłoby wchodzić $\mathrm{w}$ alians z pohańcami przeciw chrześcijanom.

3. Wołodyjowski w liście do Basi używa arcypieszczotliwego wyrażenia w fonetycznej postaci ukraińskiej; „myłeńka” 54 , co być może brzmi bardziej jeszcze proukraińsko niż poprzednio wymienione przeze mnie akcenty.

Niestety, poszukiwacz tonów propolskoukraińskich w Hoffmanowskiej ekranizacji Pana Wołodyjowskiego może być nieco zawiedziony, jeśli porówna film z powieścią. Zapewne słychać łzawą nostalgię za stepami Ukrainy w uroczej skądinąd filmowej balladzie Stepie szeroki (z wersji serialowej filmu), skomponowanej przez Wojciecha Kilara i napisanej przez Jerzego Lutowskiego, a wykonywanej przez Leszka Herdegena. Ale poza tym nie ma - w żadnej z wersji adaptacji powieści o Małym Rycerzu - innych akcentów propagandowych. W czasie realizacji tego dzieła inne były priorytety. Układ geopolityczny był sztuczny i sztywny. Oficjalnie przecież Polska była w przyjaźni z Ukrainą, która była jedną z republik ZSRR. Nie było więc potrzeby, mówiąc ironicznie, szczególnie zabiegać środkami arty-

53 Rozkaz hetmański nakazał „Wołodyjowskiemu objąć komendę w Chreptiowie, tamże nad granicą mołdawską czuwać, głosów od strony pustyni nasłuchiwać, stróżować, luźnym czambułom, zabiegać i okolicę z hajdamaków oczyścić”. H. Sienkiewicz, Pan Wołodyjowski, Warszawa 1991, s. 175.

54 Ibidem, s. 182. 
stycznymi o jakieś zbliżenie. Hoffman, przystępując do realizacji filmu, kierował się jednostronnymi potrzebami swoich rodaków, ,zapotrzebowaniem na bohatera pozytywnego”, który byłby „wzorem wzruszającego patrioty i obywatela”55. Burzliwe starcie między głównymi bohaterami, w których szczególnie świecić ma cnota Małego Rycerza, zepchnęły na drugi czy nawet trzeci plan nie tylko sprawę polsko-ukraińską, ale też obronę chrześcijaństwa czy jakiekolwiek konflikty społeczne. Idealizacja przeszłości, apoteoza narodu potrzebującego pociechy (w takim samym stopniu, jak prawie przed wiekiem, kiedy powstawała Trylogia) zdominowała każdą analizę polityczno-społeczno-historyczną. A przecież Rzeczpospolita czasów wojny z Turkami to już czas początku jej schyłku, czas gromadzących się nierozwiązanych konfliktów, między innymi gorącego konfliktu kozackiego. Cóż z tego, można by dodać z zadumą i goryczą, skoro film Hoffmana był oszałamiającym sukcesem — i to nie tylko w Polsce, lecz także na światowych ekranach ${ }^{56}$.

\section{MAZEPA (1975)}

Iwan Stepanowycz Kołedynśkyj był swego czasu, zwłaszcza w romantyzmie, postacią osławioną, barwną, męczeńską i... wielce romantyczną właśnie. Ten znakomicie wykształcony w Kijowie w Kolegium Mohylańskim, potem w kolegium jezuickim w Warszawie, szlachcic ruski, wielce zasłużony dla swojej ukraińskiej ojczyzny, a również dla Polski, swoją biografią obfitującą w różnego kalibru przygody - awanturniczo-romansowe, ale także autentycznie patriotyczno-tragiczno-męczeńskie, inspirował takich mistrzów pióra, jak George Gordon Byron, Wiktor Hugo, Aleksander Puszkin, Taras Szewczenko, Bohdana Łepkyj czy Juliusz Słowacki. Potem wabił również Bertolda Brechta i kompozytora Piotra Czajkowskiego.

Mazepa Gustawa Holoubka został zaadaptowany całkowicie filmowo — od początku realizowany był z intencją stworzenia utworu kinowego ${ }^{57}$. Nieprzypadkowo był tak właśnie filmowany, gdyż jego klasyczna, mało romantyczna konstrukcja dramaturgiczna sprzyja ekranizacji. Jest to bowiem prawie idealny utwór klasycystyczny — pięcioaktowy, niemal całkowicie respektujący zasadę trzech jedności, z francuskim podziałem na sceny odpowiadającym wejściom i wyjściom głównych osób. Przestrzeń jest w nim zamknięta, ciąg czasowy zdarzeń nie ulega zakłóceniom. Ekranizacji, ufilmowieniu Mazepy sprzyja ponadto klasyczny temat miłości, intrygi, ślepej zazdrości i tak samo klasyczne tragiczne zakończenie zdarzeń po-

55 R. Marszałek, op. cit., s. 68-69.

56 Zob. ibidem, s. 71.

57 Holoubek był świetnie przygotowany do sfilmowania Mazepy, ponieważ wcześniej wielokrotnie występował na deskach teatralnych czy w teatrze telewizji w sztukach Słowackiego, również w Mazepie; ponadto w roku 1969 wyreżyserował sztukę dla telewizji właśnie i zagrał rolę króla Jana Kazimierza. (Podobnie uczynił w roku 1992 w Teatrze Ateneum, reżyserując i grając tę samą rolę, a w następnym roku przeniósł spektakl do teatru telewizji).

Studia Filmoznawcze 37, 2016

(C) for this edition by CNS 
trójną śmiercią ${ }^{58}$. „Sztuka pisana jakby pod kątem możliwości przeciętnego teatru. Utwór prosty do wystawienia, kontynuujący tradycję gatunku"59.

W pewnym stopniu może owa „filmowość” Mazepy zaskakiwać: najmniej romantyczny dramat poety okazuje się najbardziej filmowy. A przecież to romantyzm wprowadził do sztuki dramatycznej rozluźnienie czasu i poszerzenie przestrzeni, co tak lubi przecież sztuka filmowa. Rzecz w tym, że mimo możliwości uprzestrzennienia czasu i uczasowienia przestrzeni, ,,immanentną cechą obrazu filmowego jest teraźniejszość" ${ }^{60}$. A jednak ekranizacja dramatu, jakakolwiek, oznacza zawsze jego epizację: ,(...) w toku filmowej adaptacji utworu dramatycznego dokonuje się epi zacja, a zatem poszerzenie, dopowiedzenie"61 — to opinia Marii Żmigrodzkiej. Ta epizacja dokonuje się poprzez wprowadzenie redukcji, permutacji, substytucji i — zwłaszcza — amplifikacji. Te ostatnie w filmie Holoubka to na przykład plene-

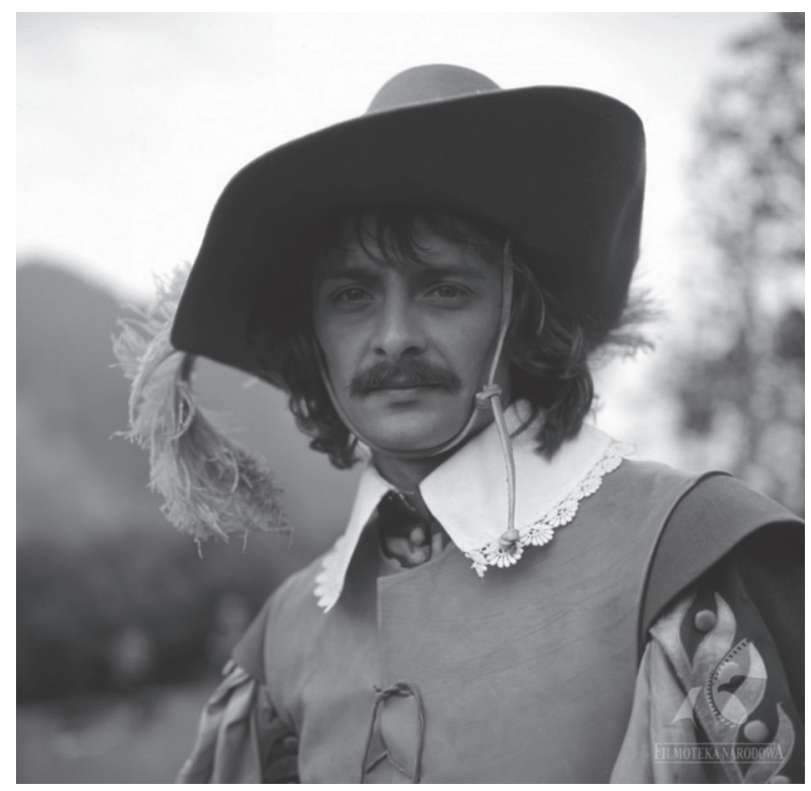

5. Jerzy Bończak w roli Mazepy. Mazepa, reż. Gustaw Holoubek, 1976, OSF KADR, SF TOR, SF ZEBRA. Filmoteka Narodowa. Licencja: SF KADR

58 Filmową atrakcyjność sztuki Słowackiego docenił kilka lat przed Holoubkiem Walerian Borowczyk, realizując w 1971 roku bardzo swobodną jej adaptację pt. Blanche. Choć dialogi pozbawione były wiersza, postacie miały inne niż u Słowackiego imiona, a Borowczyk dodał kilka motywów spoza sztuki, to i tak Holoubek, co widać wyraźnie, musiał się inspirować tym francuskim filmem. Np. scena początkowa — kąpiel Amelii z udziałem Wojewody — została z niego zapożyczona.

59 A. Kowalczykowa, Stowacki, Warszawa 1994, s. 182.

60 J. Płażewski, Język filmu, Warszawa 1982, s. 296.

61 M. Żmigrodzka, [w:] M. Janion, M. Żmigrodzka, Kostiumowy dreszczowiec czy ironiczna tragedia miłości. Dialog o filmowym Mazepie, „Kino” 1976, nr 3, s. 10.

Studia Filmoznawcze 37, 2016

(C) for this edition by CNS 
ry (poszerzenie przestrzeni licznych scen), gra planów, a szczególnie posługiwanie się zbliżeniami (zwężenie przestrzeni). W kilku scenach zastosowanie zbliżeń dało efekt intensywnego dramatyzmu, choćby podczas uwodzenia Amelii (Magdalena Zawadzka) przez lubieżnego króla polskiego Jana Kazimierza (Zbigniew Zapasiewicz) czy w czasie pożegnania Zbigniewa (Krzysztof Kolberger) z piękną macochą. W niezwykle dramatycznej scenie wznoszenia muru reżyser posłużył się nawet detalem, ukazując w maksymalnym zbliżeniu oczy przerażonej Amelii. Czasem zbliżenie, czy po prostu gra planów, wprowadza bardziej subtelny, znakowo-ironiczny element: pierwsza scena rozmowy króla z jego paziem rozpoczyna się od zbliżenia, które eksponuje płaskorzeźbę Najświętszej Marii Panny z Dzieciątkiem, przy której monarcha zmawia modlitwę Salve Regina, gratia plena i w jej trakcie przechodzi do rozmowy z paziem — do frywolnej tematyki łóżkowej. Reżyser wyraźnie drwi sobie z obłudnej katolickości polskiego króla, a może i polskiej w ogóle.

Dość licznie reprezentowane są permutacje w adaptacji Holoubka, dzięki nim narracja filmu jest bardziej spójna, dynamiczna i dramatyczna oraz wartka i płynna. Reżyser zręcznie też posłużył się obrazową substytucją, np. we wstępnej, całkowicie niedialogowej charakterystyce tytułowego bohatera, granego w filmie przez Jerzego Bończaka. W dramacie Kasztelanowa charakteryzuje słynnego Kozaka jako fircyka, wietrznika, playboya w scenie 4 aktu I. Na ekranie tych dialogowych eksplikacji nie ma. Zamiast nich obecne są dwa obrazy: na początku po prologowej sekwencji z jeźdźcem widzimy pazia na koniu, dokazującego na nim, „tańcującego”, jakby się przed kimś popisywał (towarzyszy temu „niemądra” muzyka). Potem obserwujemy go wchodzącego przez balkon do pokoju Amelii i tak następuje dalszy ciąg jego „charakterystyki” — mizdrzy się przed lustrem, wkłada na szyję korale wojewodziny, odkrywa jej alkowę, przymierza jej koszulę nocną, przygląda się kanarkowi w klatce i jak podrostek pogwizduje w kierunku ptaka.

Wprawdzie podczas realizacji Gustaw Holoubek zapowiadał „romans kryminalny"62, ale przecież udało mu się oddać tragiczny wymiar utworu Słowackiego. Krytycy piszący o filmie w czasie jego rozpowszechniania byli raczej co do tego zgodni ${ }^{63}$. Żmigrodzka i Janion w dyskusji na łamach „Kina” przyznały, że Holoubek oddał w istocie „tragedię Juliusza Słowackiego” i że jednocześnie utwór jego „to nie jest przedstawienie teatralne w kinie. To rzeczywiście jest film"64. I u Słowackiego, i u Holoubka wyeksponowane zostały te same elementy: ,junakieria, horror, zamek, dziki wybuch namiętności" 65 . Powstał, według polskich badaczek, „kostiumowy dreszczowiec”, ale jednocześnie „tragedia honoru”, „tragedia zazdro-

62 Zob. E. Smoleń-Wasilewska, Romans kryminalny, „Film” 1975, nr 24, s. 16.

63 Choćby Maria Janion czy Maria Żmigrodzka, a także: J. Niecikowski, Teatralny Mazepa, „Film” 1976, nr 16; A. Ledóchowski, Nazwisko tchórza weźmie ręka krwawa, „Film” 1976, nr 14.

${ }^{64}$ M. Janion, M. Żmigrodzka, op. cit., s. 11.

65 Ibidem, s. 13. 
ści”66. Słusznie jednak obie badaczki skłaniały się w swojej dyskusji najbardziej ku postrzeganiu filmowego Mazepy jako ironicznej tragedii miłości ${ }^{67}$, zauważając, iż Wojewoda jest na ekranie, tak jak w dramacie, pysznym magnatem, ale jednocześnie, czego u Słowackiego nie widać, zawiedzionym kochankiem - wszakże trzy razy bierze swą żonę z czułością na ręce (podczas prologowej sceny kąpieli Amelii, potem gdy żona mdleje w czasie zamurowywania Mazepy w alkowie i ostatni raz — w momencie jej śmierci).

Co do ironii romantycznej, obie krakowskie badaczki stwierdzają jej obecność w dramacie Słowackiego i filmie Holoubka.

I w gruncie rzeczy — to słowa Marii Janion - tak zwana ironia losu — wkradanie się stałego dysonansu między zamiary a spełnienia, rozmijanie się ludzkich założeń i obiektywnego sensu wydarzeń, dziwnie regularna potęga złośliwego przypadku — panuje nad wydarzeniami dramatycznymi i filmowymi ${ }^{68}$.

Rzecz w tym, że w utworze Słowackiego głównym bohaterem jest właśnie Los. Można mieć pewne wątpliwości co do tego, kto z postaci dzieła jest jego protagonistą — tytułowy Mazepa, Wojewoda czy może Zbigniew? Tę wątpliwość formułowano już wielokrotnie w opracowaniach Mazepy ${ }^{69}$. Gramatyka sztuk fabularnych podpowiada, że jeśli nie ma w świecie przedstawionym wyrazistego jednostkowego protagonisty, to musi go zastępować albo bohater zbiorowy, albo coś innego. W tym przypadku tym czymś jest Los.

Jednakże $\mathrm{z}$ drugiej strony trzeba zauważyć, również nie będąc oryginalnym czy pionierskim, że postać tytułowa dramatu — zwłaszcza z punktu widzenia reguł dramaturgii filmowej — najbardziej zasługuje na potraktowanie jako protagonisty. To przecież Mazepa, jako mityczny heros, przekracza system kulturowych tabu najpierw kontestując i kompromitując dworską moralność, czy raczej niemoralność polskiego króla, aż do zdemaskowania haniebnego spisku monarchy, a potem kompromituje sarmacką mentalność i obyczajowość wojewody. W stosunku do króla przekracza normę cynizmu i obłudy poprzez swoją uczciwość i w gruncie rzeczy niewinność, a w stosunku do wojewody przekracza tabu mizoginii i rozbuchanego, ekscesywnego patriarchalizmu.

Uwydatnienie tragicznej ironii w utworze Słowackiego i jego ekranizacji implikuje interpretację egzystencjalną. Tragizm w Mazepie w wynika z fałszywej percepcji empirycznego świata, z nieumiejętności przejrzenia pozorów, jest to tragedia nieporozumień wynikających z „nieprzejrzystości egzystencji”. Kozak Mazepa wydaje się jedyną tragiczną postacią, ponieważ jest świadomy, co naprawdę dzieje się w zamku wojewody, staje się jedyną osobą, która pojmie istotę własnego prze-

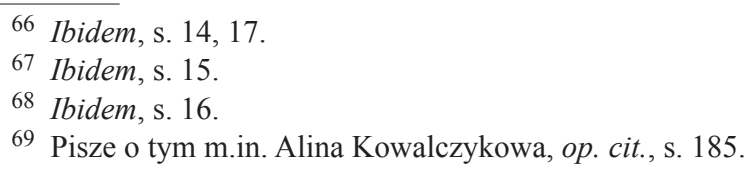


znaczenia. Pojmie przede wszystkim to, że jego los nie leży w jego rękach, bo nie on jest reżyserem na tej scenie.

W filmie Holoubka można dopatrzyć się obecności takiej perspektywy filozoficznej dzięki zastosowanym zabiegom adaptacyjnym, zwłaszcza amplifikacjom, szczególnie zabiegowi sugerowania obecności wyższej instancji nadawczej - narratora/autora implikowanego, podkreślającego tragiczną ironię. Reżyser uwydatnił jego totalizujący punkt widzenia. Ów niewidzialny obserwator, ktoś, kto „przewraca stronice opowieści", stara się wyeksponować pułapkę losu uczestników dramatu — lubieżność polskiego króla, mściwość i zapiekłość wojewody, żarliwość w miłości i czystość moralną Zbigniewa czy w końcu masochistyczno-ofiarniczy rys osobowości Amelii oraz — najważniejsze być może — niewinność i szlachetność postaci Kozaka Mazepy. Obecność owego „narratora” ujawnia się na przykład w swobodnym zachowaniu kamery, która — często w ruchu — jest w pewnym sensie niezależna od fabuły, jakby reżyserowi zależało na stworzeniu wrażenia, że ktoś przy jej pomocy opowiada/prezentuje zdarzenia. W końcówce sekwencji z jeźdźcem otwierającej film kamera ukazuje go pośród trawy od przodu, potem obraca się powoli o 180 stopni, filmując go przez cały czas i następnie już demonstruje od tyłu, kiedy dojeżdża do widniejącego w oddali obozu wojskowego. Wówczas kamera jakby ukrywa się staranniej wśród zarośli i widzimy wspomniany obóz spoza nich. Można mieć wrażenie, że ktoś opowiada-demonstruje zdarzenia. Takich sytuacji narracyjnych jest znacznie więcej.

Tę obecność osoby spoza świata przedstawionego, która pracuje nad oddaniem tragicznego splatania losów, działań i zachowań bohaterów, widać zwłaszcza w eksponowaniu wzajemnego podpatrywania się bohaterów. Reżyser przeplata poszczególne sceny zbliżeniami twarzy głównych postaci obserwujących z ukrycia innych, co potęguje atmosferę nieufności, podejrzeń: na przykład we wspomnianej scenie kąpieli Zbigniew podgląda ojca i macochę; po tańcach Amelia w ogrodzie jakby się ukrywała, za nią podąża Zbigniew, a następnie obserwuje scenę spotkania Amelii z Mazepą; przed rozpoczęciem sceny 1 aktu II Amelia w ogródku biegnie nad strumykiem, wbiega do domu, a w planie pierwszym pokazuje się wojewoda pod drzewem, jakby obserwował swoją młodą żonę; przed zabraniem Mazepy na rozmowę przez króla ten pierwszy jest obserwowany przez Zbigniewa; z kolei scena 7 aktu II (wojewoda i Zbigniew) rozpoczyna się sugestią, iż wojewoda czyhał na Zbigniewa, a potem widz ma wrażenie, jakby obaj ci bohaterowie obserwowali pazia i króla. Wszystkie te zabiegi sugerujące wzajemne podglądanie się i śledzenie bohaterów uwydatniają uwięzienie we wzajemnej obsesyjnej nieufności i niechęci, w swoich namiętnościach, fobiach i idiosynkrazjach, w pułapce zgotowanej przez los. Pułapce, w której stary satrapa Wojewoda ma prawo żenić się z młódką i więzić jej naturalne namiętności i urodę, a przy tym krzywdzić swego pierworodnego syna, wystawiając na pokusę kazirodztwa; w której monarcha wielkiego królestwa jest głupszy i moralnie znacznie niższy od swego pazia, reprezentującego lud skolonizowany. 
Oczywiście zdarzają się sytuacje, w których punkt widzenia bezsprzecznie przynależy do bohaterów. Czasem jest to chwyt konwencjonalny, ale kondensujący i upłynniający narrację. Ale dwa razy takie subiektywizacje mają wymiar bardziej symboliczny. Gdy Zbigniew po scenie kąpieli macochy patrzy z żarem w oczach wprost do kamery oraz gdy Mazepa czyni to samo w rozmowie z królem, deklarując, że dla Amelii nie tylko mógłby skaleczyć się, ale też i ugodzić we własne serce, wówczas można mieć wrażenie, iż obydwaj młodzi bohaterowie są niejako świadomi, albo mają przeczucie, ironii losu, tragizmu zdarzeń, które się rozgrywają czy rozegrają. I Słowacki, i Holoubek dokonali wyraźnego zbliżenia między pięknym, szlachetnym Zbigniewem, skłóconym ze swoim psychopatycznym ojcem-magnatem, Zbigniewem stanowiącym w znacznym stopniu „bliskiego krewnego" polskich wrażliwców, romantycznych bohaterów narodowych, a subtelnym, inteligentnym, dzielnym i równie jak Zbigniew szlachetnym Kozakiem Mazepą. To oni są najtragiczniejszymi postaciami sztuki, upostaciawiając ofiarę młodych Polaków i Rusinów - jaką sobie Rzeczpospolita magnacka często fundowała, aby trwać w swoim kolonialnym kroju.

\title{
UKRAINIAN THEMES IN POLISH CINEMA UNTIL 1989
}

\author{
Summary
}

In postwar Poland three films were created that alluded directly to the fights of the Polish Communistic Army against the Ukrainian Uprising Army and the Polish Home Army, which took place in Bieszczady at the end of the Second War and in the following several months. These were: Sergeant Major Kaleń (Ewa and Czesław Petelscy, 1961), The Ruptured Bridge (Jerzy Passendorfer, 1962), Woolves' Echos (Aleksander Ścibor-Rylski, 1968). They were all made to create the myth of Bieszczady, to achieve a propaganda effect. They also all have a form close to that of the western which was a very popular genre in Poland in the time of their making. This form was to make the realization of the mythologizing and propaganda task easier. In Sergeant Major Kaleń the main topic is a military conflict between some troops of the Polish Communistic Army and Ukrainian insurgents just after the end of the Second World War. The movie was an attempt to show the complicated social-political situation of the period in the south-eastern edge of Poland - in Bieszczady. But it was an attempt strongly ideological and dishonest from the point of view of the historical and political truth. The movie has an interesting protagonist, it depicts quite suggestively some human types from Bieszczady of those times, but it is not just in showing "the Ukrainian question" as well as the Polish Home Army and its brave and tragic "cursed soldiers". Although it should be pointed out that from the historical-political perspective the film is much more honest than the novel by Jan Gerhard Łuny w Bieszczadach [The Glow in Bieszczady] of which it was an adaptation. The Ukrainians and the soldiers of the Polish Home Army in the film by the Petelskis are cruel and ruthless, and only the soldiers of the Communist Polish army are good and honest people. The Ruptured Bridge is also an image touching upon the matter of Polish-Ukrainian struggles just before the end of the Second World War and shortly after that, but it is mainly a splendid film of adventure with some distinctive features of western and criminal-spy-sensational genre. It was based on the short story Śniegi płyną (The Snows Are Flowing) by Roman Bratny. This is a really good movie that is not as strongly soaked with communistic propaganda 
as the previous one that does not show the soldiers of UPA (Ukrainian Uprising Army) as monsters. It is rather universal in its message its epicenter is the beautiful — brave and heroic - attitude of a shire officer who is also an engineer. Similarly to Sergearnt Major Kalen the literary prototype was much more historically and politically dishonest than its screen adaptation. In Bratny's short story visible are some postcolonial accents. The Ukrainians are showed as a society culturally retarded, primitive, wild, while Passendorfer's film seems to suggest that this possible cultural latency of Ukraine was caused by the historical faults of Russia and Poland that in the past had treated Ukraine as their colony. Besides Passendorfer shows this "wildness" of the Ukrainian soldiers in some romantic aura of "Ruthenian falcons". In turn, Woolves' Echos is an unpretentious adventure film, lacking political-historical ambitions, successfully shot from its beginning to an end in a western convention. The plot takes place in Bieszczady, a few years after the Second World War. When we measure the gravity of problems separating Poles and Ukrainians after WWII, problems which had never been solved or explored in the Polish People's Republic, then Woolves' Echos appears to be compromising for the director, producers and for the Polish People's Republic's film authorities of those times. Tadeusz Lubelski once wrote: "The authors [of the movie] did not see to any authentication of the complicated story matters, the most important of which was the real conflict on the Polish-Ukrainian frontier". Two more movies with clear Ukrainian motives were made in the later years of film development in the Polish People's Republic. Mr. Wołodyjowski (Jerzy Hoffman, 1969) and Mazepa (Gustaw Holoubek, 1975). The first one was an adaptation of a novel with the same title, written by Henryk Sienkiewicz. The second movie was a film adaptation of a romantic drama written by Juliusz Słowacki also with the same title. In Sienkiewicz's novel, the last volume in his trilogy which is very significant for the shape of cultural and historical relations between Poles and Ukrainians, we can find a few very pro-Ukrainian-and-Polish motives (e.g. a widely depicted beautiful story of a difficult Polish-Ukrainian relation between Muszalski and Dydiuk - from consuming hatred up to fervent friendship). In Holoubek's Mazepa, in turn, the pro-Ukrainian/pro-Ruthenian accent is strongly visible. Eponymous Mazepa — in the time of the action of Słowacki's play (and — of course — film), being a pageboy of the Polish King Casimir — is along with the protagonist Zbigniew the most noble and upstanding character in the movie. They are both also the most tragic heroes of the play, personalizing the sacrifice of young people — the Poles and the Ruthenians - that the lordly Poland quite often made in its history to last in its colonial shape.

Translated by Stawomir Bobowski 